\title{
UPAYA MENINGKATKAN KEMAMPUAN PEMECAHAN MASALAH MENGGUNAKAN PENDEKATAN PEMBELAJARAN SAINTIFIK PADA MATERI POKOK SISTEM PENCERNAAN PADA MANUSIA DI KELAS VIII SMP PUTRA JAYA STABAT TAHUN PELAJARAN 2018/2019
}

\author{
KHAIRINA AFNI \\ STKIP Budidaya Binjai - Sumatera Utara \\ Email : khairinaafni89@gmail.com
}

\begin{abstract}
ABSTRAK
Tujuan Penelitian ini untuk mengetahui apakah pendekatan pembelajaran saintifik dapat meningkatkan hasil belajar siswa pada materi pokok sistem pencernaan pada manusia di kelas VIII SMP Putra Jaya Stabat Tahun Pelajaran 2018/2019. Penelitian ini merupakan penelitian tindakan kelas. Pendekatan yang digunakan dalam penelitian ini adalah pendekatan kualitatif. Subjek penelitian ini adalah siswa semester ganjil kelas VIII SMP Putra Jaya Stabat Tahun Pelajaran 2018/2019 yang berjumlah 35 siswa. Objek dalam penelitian ini adalah Upaya meningkatkan kemampuan pemecahan masalah menggunakan pendekatan pembelajaran saintifik pada materi pokok sistem pencernaan pada manusia di kelas VII SMP Putra Jaya Stabat Tahun Pelajaran 2018/2019. Alat yang digunakan untuk mengumpulkan data adalah tes, wawancara dan observasi. Penelitian ini terdiri dari dua siklus, masing-masing siklus terdiri dari 3 kali pertemuan belajar. Pada siklus I peneliti memberikan model pembelajaran secara klasikal. Peneliti memberika Tes KPM I pada akhir. Pada siklus II peneliti memberikan metode pendekatan pembelajaran saintifik secara berpasang-pasangan dan pada akhir siklus II peneliti memberi tes KPM II. Hasil analisis data diperoleh peningkatan hasil belajar siswa dan tes diagnostik, tes KPM I dan tes KPM II. Secara berturut-turut peningkatan hasil belajar siswa tersebut yaitu dari tes diagnostik siswa yang tuntas adalah 2 siswa $(7,14 \%)$, tes KPM I siswa yang tuntas adalah 22 siswa $(78,57 \%)$ dan tes KPM II siswa yang tuntas adalah 24 siswa (85,71\%). Ini berarti hasil yang diperoleh dari tes KPM II pada siklus II telah mencapai tingkat ketuntasan belajar dan meningkatkan hasil belajar siswa
\end{abstract}

Kata Kunci : Pemecahan Masalah, Pendekatan Saintifik, Sistem Pencernaan

\section{PENDAHULUAN}

Kemampuan pemecahan masalah dapat dilihat sebagai salah satu dari proses dan hasil belajar. Menurut S. Nasution yang mengatakan "Mereka belum mampu melihat kemungkinan-kemungkinan alternatif untuk memecahkan masalah. Dalam mengajarkan konsep-konsep pokok, penting sekali membantu anak berpikir secara bertahap dari berpikir konkrit menuju ke arah berpikir secara abstrak.

Hasil observasi pada bulan Mei yang dilakukan peneliti terhadap siswa kelas VIII SMP Putra Jaya Stabat menunjukan bahwa nilai ratarata tes diagnostik pada materi sistem pencernaan dari 35 siswa, hanya 7 orang siswa yang memenuhi KKM dan 28 orang siswa lainnya tidak memenuhi nilai KKM. Dalam setiap 
langkah kegiatan pemecahan masalah siswa dikategorikan dalam kemampuan sangat rendah, karena itu diambil kesimpulan bahwa kemampuan pemecahan masalah masih rendah.

Berdasarkan observasi dan wawancara dikelas tersebut, strategi yang digunakan guru dalam mengajar adalah ekspositori. Guru menerangkan pada awal pembelajaran sebagai pengantar terhadap materi yang akan dipelajari. Setelah itu guru membagi siswa dalam kelompok-kelompok kecil yang masing-masing kelompok terdiri dari 4 orang siswa. Guru membagikan LKS (Lembar Kerja Siswa) kepada setiap kelompok yang berisi soal untuk didiskusikan.

Selama proses diskusi, sebagian kelompok harus terlibat anggota-anggotanya mengerjakan LKS secara individu. Sehingga dalam satu kelompok belum terdapat komunikasi antarsiswa. Interaksi antarsiswa masih sangat kurang. Selain itu,diskusi pada beberapa kelompok juga belum melibatkan setiap anggotanya. Diskusi hanya didominasi oleh beberapa siswa saja. Siswa lain pasif dalam mengemukakan pendapatnya. Dari sini terlihat bahwa siswa masih belum maksimal dalam menggunakan diskusi kelompok sebagai media belajar. Akibatnya, ketika dihadapkan dengan persoalan dalam mememcahkan masalah, siswa kurang mampu untuk menyelesaikannya.

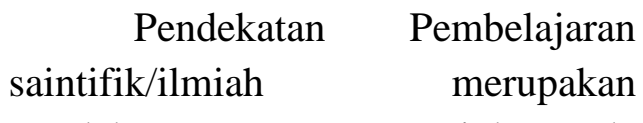

Pendekatan yang merujuk pada teknik-teknik investigasi atas fenomena atau gejala, memperoleh pengetahuan baru, atau mengoreksi dan memadukan pengetahuan sebelumnya. roses pembelajaran yang dirancang sedemikian rupa agar peserta didik secara aktif mengonstruk konsep, hukum atau prinsip melalui tahapan-tahapan mengamati (untuk mengidentifikasi atau menemukan masalah), merumuskan masalah, mengajukan atau merumuskan hipotesis, mengumpulkan data dengan berbagai teknik, menganalisis data, menarik kesimpulan dan mengomunikasikan konsep, hukum atau prinsip yang "ditemukan"

$$
\text { Dalam }
$$

pendekatan pembelajaran saintifik ini, diperlukan suatu teknik pembelajaran yang menempatkan siswa menjadi subjek aktif melalui tahapan-tahapan ilmiah sehingga mampu mengkonstruk pengetahuan baru atau memadukan dengan pengetahuan sebelumnya. Pendekatan saintifik/ ilmiah terbukti lebih efektif dalam pembelajaran dibandingkan dengan pembelajaran tradisional. Peran guru tentu sangat penting yaitu sebagai pembimbing kegiatan belajar siswa. Guru menjadi pemandu bagi kegiatan siswa dalam menemukan sebuah konsep dengan 
cara memberikan pertanyaanpertanyaan stimulus, mengaitkan permasalahan yang ada dengan kehidupan sehari-hari serta memberikan motivasi yang dapat mengarahkan siswa untuk menemukan konsep dan suatu prinsip. Hal ini berkaitan dengan anjuran kurikulum saat ini. Diharapkan dalam proses pendekatan pembelajaran saintifik ini, siswalah yang harus aktif dan guru hanyalah sebagai fasilitator dan motivator.

Berdasarkan masalah yang telah diuraikan, maka rumusan masalah dalam penelitian ini adalah: Bagaimana Upaya meningkatkan kemampuan pemecahan masalah menggunakan pendekatan pembelajaran saintifik pada materi pokok sistem pencernaan pada manusia di kelas VII SMP Putra Jaya Stabat Tahun Pelajaran 2018/2019?

\section{TUJUAN PENELITIAN}

Berdasarkan

rumusan

masalah yang telah dikemukakan maka tujuan penelitian ini adalah untuk mengetahui Upaya meningkatkan kemampuan pemecahan masalah menggunakan pendekatan pembelajaran saintifik pada materi pokok sistem pencernaan pada manusia di kelas VII SMP Putra Jaya Stabat Tahun Pelajaran 2018/2019.

\section{KAJIAN LITERATUR DAN TEORI}

\section{Pengertian Belajar}

Kata "belajar" merupakan kata yang tidak asing bagi kita, hampir seluruh kegiatan kita diawali dengan belajar. Misalnya, kita mengenakan pakaian, kita makan menggunakan alat-alat makan, kita berkomunikasi satu sama lain menggunakan bahasa nasional, dan lain sebagainya. Halhal tersebut tidak mungkin kita lakukan tanpa proses belajar lebih dahulu. Akan tetapi, dari semua itu tidak semua orang mengetahui apa itu belajar. Dan secara umum pengertian belajar adalah mengumpulkan sejumlah pengetahuan, dimana pengetahuan tersebut diperoleh dari orang yang lebih tahu atau ahli yang sekarang banyak dikenal dengan guru.

\section{Kemampuan Pemecahan}

\section{Masalah}

Dalam kamus besar bahasa Indonesia (2001) dikemukakan bahwa : "kemampuan adalah kesanggupan”. Kecakapan seseorang dalam melakukan sesuatu aktifitas. Setiap orang memiliki kemampuan yang berbeda-beda baik dalam menerima, mengingat maupun menggunakan sesuatu yang diterimanya. Hal ini disebabkan bahwa setiap orang memiliki cara yang berbeda dalam hal menyusun 
segala sesuatu yang diamati, dilihat, diingat maupun dipikirkannya. Siswa juga dapat berbeda dalam cara menerima, mengorganisasikan dalam cara pendekatan terhadap situasi belajar dan menghubungkan pengalaman-pengalamannya tentang pelajaran serta cara mereka merespon terhadap metode pengajaran.

\section{Pendekatan Pembelajaran Saintifik}

\begin{tabular}{rr}
\multicolumn{2}{c}{ Penerapan pendekatan } \\
saintifik dalam pembelajaran
\end{tabular}
melibatkan keterampilan proses seperti mengamati, mengklasifikasi, mengukur,meramalkan, menjelaskan, dan menyimpulkan. Pendekatan ilmiah (scientific appoach) dalam pembelajaran sebagaimana dimaksud meliputi mengamati, menanya, menalar, mencoba, dan membentuk jejaring $(5 \mathrm{M})$.

\section{Pendekatan ini merujuk} kepada teknik-teknik investigasi atas suatu fenomena, cara memperoleh pengetahuan baru, atau mengoreksi dan memadukan dengan pengetahuan sebelumnya. Berikut ini pemaparan langkah-langkahnya:

1) Mengamati

Metode mengamati mengutamakan kebermaknaan proses pembelajaran. Keunggulan metode mengamati adalah peserta didik senang dan tertantang dan mudah pelaksanaannya.

2)Menanya

Menanya menurut Kemendikbud mempunyai fungsi sebagai berikut: (a) Membangkitkan rasa ingin tahu, minat, dan perhatian peserta didik.

(b) Mendorong dan menginspirasi peserta didik untuk aktif belajar, serta mengembangkan pertanyaan dari dan untuk dirinya sendiri.

(c) Mendiagnosis kesulitan belajar peserta didik sekaligus menyampaikan ancangan untuk mencari solusinya.

(d) Menstrukturkan tugas-tugas dan memberikan kesempatan kepada peserta didik untuk menunjukkan sikap, keterampilan, dan pemahamannya atas substansi pembelajaran yang diberikan.

(e) Membangkitkan keterampilan peserta didik dalam berbicara, mengajukan pertanyaan, dan memberi jawaban secara logis, sistematis, dan menggunakan bahasa yang baik dan benar.

(f) Mendorong partisipasi peserta didik dalam berdiskusi, berargumen, mengembangkan kemampuan berpikir, dan menarik simpulan.

(g) Membangun sikap keterbukaan untuk saling memberi dan menerima pendapat atau gagasan, memperkaya kosa kata, serta mengembangkan toleransi sosial dalam hidup berkelompok.

(h) Membiasakan peserta didik berpikir spontan dan cepat, serta sigap dalam merespon persoalan yang tiba-tiba muncul. 
(i) Melatih kesantunan dalam berbicara dan membangkitkan kemampuan berempati satu sama lain.

\section{3)Mengumpulkan}

data/

Mengekplorasi

Mengumpulkan data artinya siswa diajak untuk mengumpulkan pengetahuan sebanyak dari berbagai sumber pengetahuan

\section{4)Menalar}

Penalaran adalah proses berfikir yang logis dan sistematis atas fakta empiris yang dapat diobservasi untuk memperoleh simpulan berupa pengetahuan. Aplikasi metode eksperimen atau mencoba dimaksudkan untuk mengembangkan berbagai ranah tujuan belajar, yaitu sikap, keterampilan, dan pengetahuan.

\section{5)Mengkomunikasikan}

Situasi kolaboratif peserta didik akan dilatih berinteraksi dengan empati, saling menghormati, dan menerima kekurangan atau kelebihan masingmasing.

\section{PENELITIAN RELAVAN}

Adapun penelitian yang relevan terhadap penelitian yang dilakukan peneliti adalah penelitian dengan judul Pengembangan Multimedia Pembelajaran Interaktif Berbasis Pendekatan Saintifik untuk Meningkatkan Penguasaan Konsep Sistem Pencernaan Siswa Kelas XI IPA MAN Malang 2 Kota Batu menyatakan bahwa pembelajaran interaktif berbasis pendekatan saintifik ini layak digunakan dalam pembelajaran dan dapat meningkatkan penguasaan konsep sistem pencernaan pada siswa. Hal ini berdasarkan hasil analisis data validasi ahli materi diperoleh prosentase pencapaian kelayakan produk sebesar $85,52 \%$, validasi ahli media $86,67 \%$, dan uji coba lapangan $76,60 \%$ yang berarti produk layak digunakan. Selain itu skor rata-rata siswa dalam meningkatkan penguasaan konsep adalah 91 yang berarti nilai melebihi KKM yaitu 75 dan meningkat dari nilai yang diperoleh sebelumnya yaitu 60 .

\section{METODE PENELITIAN}

Penelitian ini akan dilaksanakan di kelas VIII SMP Putra Jaya Stabat yang beralamat di Jalan Perdamaian No. 59 Stabat.

Subjek Penelitian Adapun yang menjadi subjek penelitian ini adalah siswa kelas VIII SMP Putra Jaya Stabat, yang berjumlah 35 siswa yang terdiri dari 12 orang laki-laki dan 23 orang perempuan.

Adapun yang menjadi objek penelitian ini adalah penerapan pendekatan pembelajaran saintifik untuk meningkatkan kemampuan pemecahan masalah siswa.

Jenis penelitian ini adalah Penelitian Tindakan Kelas (Classroom Action Research). Pendekatan yang digunakan adalah pendekatan kualitatif yang berguna 
untuk mengungkapkan kesulitan belajar siswa dalam mempelajari materi sistem pencernaan serta cara mengatasi kesulitan-kesulitan tersebut sebagai upaya untuk meningkatkan hasil belajar dan meningkatkan kemampuan pemecahan masalah siswa.

\section{SIKLUS I}

\section{Tahap Perencanaan}

Tahap ini dilakukan setelah tes awal. Kemudian hasil tes awal tersebut digunakan untuk identifikasi awal terhadap tindakan yang akan dilakukan. Selanjutnya tindakan yang dilakukan pada tindakan ini adalah merencanakan tindakan berupa penyusunan rencana pelaksanaan pembelajaran (RPP), penyusun kegiatan pengamatan dan tindakan tes. Dalam penyusunan rencana pelaksanaan pembelajaran (RPP) disesuaikan dengan tingkat kesulitan siswa, untuk itu diperlukan model ataupun pendekatan pembelajaran dalam kegiatan mengajar tersebut yaitu dengan menggunakan Sterategi Pendekatan saintifik

\section{Tahap Pelaksanaan Tindakan I}

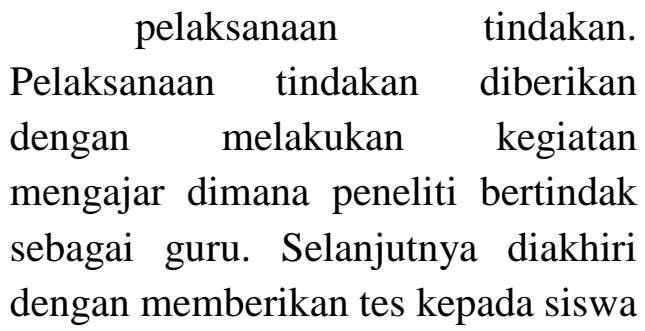

untuk mengetahui hasil yang dicapai melalui pemberian tindakan.

\section{Observasi I}

Observasi dilakukan didalam kelas saat kegiatan belajar mengajar berlangsung. Observasi dilakukan oleh guru biologi kelas VIII SMP Putra Jaya Stabat. Adapun perannya adalah mengamati aktivitas pembelajaran yang berpedoman pada lembar observasi yang telah disiapkan.

\section{Refleksi I}

Tahap ini dilakukan untuk menganalisa dan memberikan arti terhadap data yang diperoleh, memperjelas data, serta dilakukan analisa atas catatan-catatan kecil yang diperoleh melalui tahap observasi sehingga didapat kesimpulan dari tindakan yang dilakukan.

\section{PEMBAHASAN DAN HASIL PENELITIAN}

Sebelum penelitian dilakukan, siswa diberikan tes diagnostik sehingga diperoleh kemampuan siswa dalam memecahkan masalah, terdapat 4 orang dari 35 siswa atau $4,76 \%$ yang memiliki tingkat kemampuan sedang, 8 siswa atau $14,29 \%$ memiliki tingkat kemampuan rendah, dan 23 siswa atau $80,95 \%$ yang memiliki tingkat kemampuan sangat rendah. Hasil ini 
menunjukkan bahwa tingkat kemampuan siswa memecahkan masalah masih rendah. Salah satu upaya yang dilakukan untuk mengatasi dan meningkatkannya adalah melalui pembelajaran dengan pendekatan pemebelajaran saintifik.

Setelah pemberian tindakan pada siklus I yang diberikan kepada 35 siswa, diperoleh rata-rata kemampuan siswa memahami masalah adalah 13,03 $(81,47 \%)$, ratarata kemampuan siswa merencanakan pemecahan masalah adalah $32,75 \quad(72,77 \%)$, rata-rata kemampuan siswa melaksanakan pemecahan masalah adalah 27,78 $(79,38 \%)$ dan rata-rata siswa memeriksa kembali solusi yang diperoleh adalah 3,14 $(69,64 \%)$.

Tingkat kemampuan siswa memecahkan masalah pada tes kemampuan pemecahan masalah I siklus I adalah sedang dengan nilai rata-rata 76,5 dengan jumlah siswa yang telah mencapai tingkat ketuntasan belajar adalah 25 siswa $(78,57 \%)$, sedangkan 10 siswa $(21,43 \%)$ belum mencapai tingkat ketuntasan belajar. Hasil ini belum sesuai yang diharapkan, sehingga dilanjutkan ke siklus II. Upaya yang dilakukan untuk mengatasi kesulitan belajar siswa dan meningkatkan kemampuan memecahkan masalah adalah dengan melakukan bimbingan yang lebih intensif kepada siswa yang memiliki kemampuan rendah, metode tanya jawab lebih ditekankan dan lebih menjelaskan kepada siswa langkah-langkah pemecahan masalah Polya. Selain itu, sebelum proses pembelajaran guru menugaskan siswa untuk membaca atau melihat kejadian sehari-hari yang berhubungan dengan materi yang akan dibahas.

Setelah pemberian tindakan pada siklus II diperoleh rata-rata kemampuan siswa memahami masalah adalah 15,14 $(91,52)$, ratarata kemampuan siswa merencanakan pemecahan masalah adalah 35,32 $(75,15 \%)$, rata-rata kemampuan siswa melaksanakan pemecahan masalah adalah 30,07 $(91,12 \%)$ dan rata-rata siswa memeriksa kembali solusi yang diperoleh adalah 3,39 (87,5\%). Diperoleh bahwa tingkat kemampuan siswa memecahkan masalah pada tes kemampuan pemecahan masalah II pada siklus II adalah tinggi dengan nilai rata-rata 80,82 dengan jumlah siswa yang telah mencapai tingkat ketuntasan belajar adalah 29 siswa $(85,72 \%)$, sedangkan jumalah siswa yang belum mencapai tingkat ketuntasan belajar hanya 6 siswa $(14,28 \%)$. Hal ini menunjukkan keberhasilan dari tindakan yang telah dilakukan.

Data penelitian yang diperoleh dari siklus I dan siklus II ditemukan bahwa kemampuan pemecahan masalah siswa pada siklus II lebih tinggi daripada siklus 
I. Pada tes kemampuan pemecahan masalah I di siklus I nilai rata-rata 76,5 sedangkan pada tes kemampuan pemecahan masalah II di siklus II nila rata-rata 80,82 . Nilai rata-rata meningkat sebesar 4,32 dari tes kemampuan pemecahan masalah I.

Dari segi ketuntasan belajar siswa pada siklus I terdapat 25 siswa (78,57\%) mencapai tingkat ketuntasan belajar, sedangkan pada siklus II sebanyak 29 siswa (85,70\%). Dengan demikian diperoleh peningkatan ketuntasan belajar siswa sebesar 4,32\%. Hal ini membuktikan bahwa penggunaan pendekatan pembelajaran saintifik dalam pembelajaran biologi dapat diterapkan untuk meningkatkan kemampuan pemecahan masalah siswa.

\section{KESIMPULAN}

Kesimpulan yang dapat ditarik dari hasil penelitian ini adalah :

Tingkat kemampuan siswa memecahkan masalah pada tes diagnostik diperoleh skor rata-rata siswa dalam pemecahan masalah adalah 23,88 (36,74\%) dengan 6 siswa atau $7,14 \%$ dari 35 siswa telah mencapai tingkat ketuntasan belajar. Setelah dilakukan tindakan pada siklus I dengan diajar menggunakan pendekatan santifik diperoleh tingkat kemampuan siswa memecahkan masalah adalah sedang dengan nilai rata-rata kelas 76,5 atau 25 siswa
$(78,57 \%)$ dari 35 siswa telah mencapai tingkat ketuntasan belajar secara individu. Selanjutnya setelah pelaksanaan tindakan pada siklus II, diketahui tingkat kemampuan siswa memecahkan masalah adalah tinggi dengan nilai rata-rata kelas 80,82 dengan jumlah siswa yang telah mencapai tingkat ketuntasan belajar secara individu sebanyak 29 siswa atau $85,72 \%$ dari 35 siswa.

\section{Sedangkan nilai KKM SMP} Putra Jaya adalah 76. Berdasarkan analisis data penelitian, diperoleh gambaran bahwa pendekatan pembelajaran saintifik dapat meningkatkan kemampuan pemecahan masalah siswa kelas VIII SMP Putra Jaya pada materi pokok sistem pencernaan, dimana peningkatan diperoleh setelah siklus II dilaksanakan.

\section{SARAN}

Adapun saran yang dapat diambil dari hasil penelitian ini, yaitu :

1. Kepada guru IPA khususnya guru Biologi SMP Putra Jaya Stabat agar melibatkan siswa dalam proses belajar mengajar, dan menggunakan pendekatan pembelajaran saintifik sebagai salah satu alternatif pendekatan pembelajaran untuk meningkatkan kemampuan siswa dalam memecahkan masalah. 
2. Kepada siswa SMP Putra Jaya Stabat disarankan lebih aktif dalam menemukan sendiri konsep matematika dan berani untuk menanyakan hal-hal yang kurang dipahami kepada guru untuk menemukan konsep itu dan lebih berani dalam menyampaikan pendapat atau ide-ide, dapat mempergunakan seluruh potensi yang dimiliki dalam pelajaran matematika.

3. Kepada peneliti lanjutan agar hasil penelitian ini dapat dijadikan pertimbangan untuk menggunakan pembelajaran realistik pada materi ajar yang dapat dikembangkan untuk penelitian selanjutnya. 


\section{DAFTAR RUJUKAN}

Arikunto, Suharsimi .(2013). Prosedur Penelitian, Rineka Cipta, Jakarta.

Amustofa .(2009). Strategi Pemecahan Masalah dalam Matematika, http://amustofa 70.wordpress.com (diakses pada tanggal 24 Agutus 2017).

D.E,Puspitasari.2014.Pengembangan Multimedia Pembelajaran Interaktif Berbasis Pendekatan Saintifik untuk Meningkatkan Penguasaan Konsep Sistem Pencernaan Siswa Kelas XI IPA MAN Malang 2 Kota Batu. Skripsi. Program Studi Pendidikan Biologi Jurusan Biologi FMIPA Universitas Negeri Malang. http://karyailmiah.um.ac.id/index.php/biol ogi/article/view/36310

Dimyati, Mudjiono .(2006). Belajar dan Pembelajaran, Rineka Cipta, jakarta.

Djamarah,Z .(2006). Strategi Belajar Mengajar, Penerbit Rineka Cipta, jakarta.

Jaya, Indra .(2010). Statistik Penelitian Untuk Pendidikan, Citapustaka Media Perintis, Bandung.
Jupri, Al .(2009). Pendekatan

Pemecahan Masalah, Universitas Pendidikan Indonesia, Bandung.

Kunandar .(2008). Langkah Mudah Penelitian Tindakan Kelas Sebagai Pengembangan Profesi Guru, Raja Grafindo Persada, Jakarta.

Muslich, Masnur .(2008). KTSP Pembelajaran Berbasis Kompetensi dan Kontekstual, Bumi Aksara, Jakarta.

Nasar .(2006). Merancang Pembelajaran Aktif dan Kontekstual Berdasarkan "SISKO” Grafindo, Jakarta.

Trianto .(2008). Mendesain Pembelajaran Kontekstual, Cerdas Pusataka, Jakarta.

Tri Lukitaningsih. Peningkatan Pencapaian Kompetensi Siswa Kelas VIII G SMP Negeri 2 Paron Pada Materi Sistem Pencernaan Manusia Dengan Pendekatan Saintifik Melalui Media Puzzle . Jurnal Florea Volume 2 No. 1, April 2015 (2-12) 